\title{
Materials engineering for a better global environment
}

\author{
KIYOTAKA WASA \\ Research Institute of Innovative Technology for the Earth, 9-2, Kizugawadai, Kizu-cho, \\ Soraku-gun, Kyoto 619-02. Japan
}

MS received 22 May 1995; revised 25 August 1995

\begin{abstract}
The role of materials engineering including ceramics technology for a better global environment is discussed. Present global environmental issues will be solved by resourceful energy technology and waste management under a minimum pollution of environment. The materials technology will play an important role to mitigate the global environmental issues. Research program on future energy technology and waste management should be considered according to a condition of domestic and/or international regulation. Energy saving and domestic waste management including pollution prevention of atmosphere, water and soil are near term research areas. Medium and long term research areas are non-fossil energy technology and global waste management including removal and/or reuse of greenhouse gas $\mathrm{CO}_{2}$ and nuclear waste management. To mitigate future global environmental issues, traditional materials technology should be reconstructed to build environment benign materials technology which could provide minimum environmental load.
\end{abstract}

Keywords. Environment; materials; ceramics; energy saving; low temperature sintering; waste management.

\section{Introduction}

At the 1992 UNCED(United Nations Conference on Environment and Development) conference on the area relating to the sustainable development of the planet from now until the 21st century, known as the Earth Summit in Rio de Janeiro, the global environmental issues including acid rain, global warming, and depletion of ozone layer provided a growing international debate. The present global environmental issues are caused by excess energy consumption and recent marked growth of population, which are essentially embedded in the scientific and technological advances since the 'Industrial Revolution'. Establishment of a novel environmental technology with a radical reform of present economic and social system is now required for the achievement of a better global environment.

A variety of environmental technologies including energy saving, clean energy and/or renewable energy, waste management, and materials recycling are now being studied in the world. Among these environmental technologies ceramics materials technology will be one of a key technology to establish the practical environmental technology. This paper will describe the scientific technologies for a better global environment and discuss environment benign materials engineering.

\section{Scientific technologies}

The present global environmental issues are essentially related to the potential of energy supply and environment protection under given numbers of populations. At present to counter-measure the present global environmental issues several scientific technologies including monitoring and modelling global climate/environment change, 
Table 1. Scientific technologies for a better global environment.

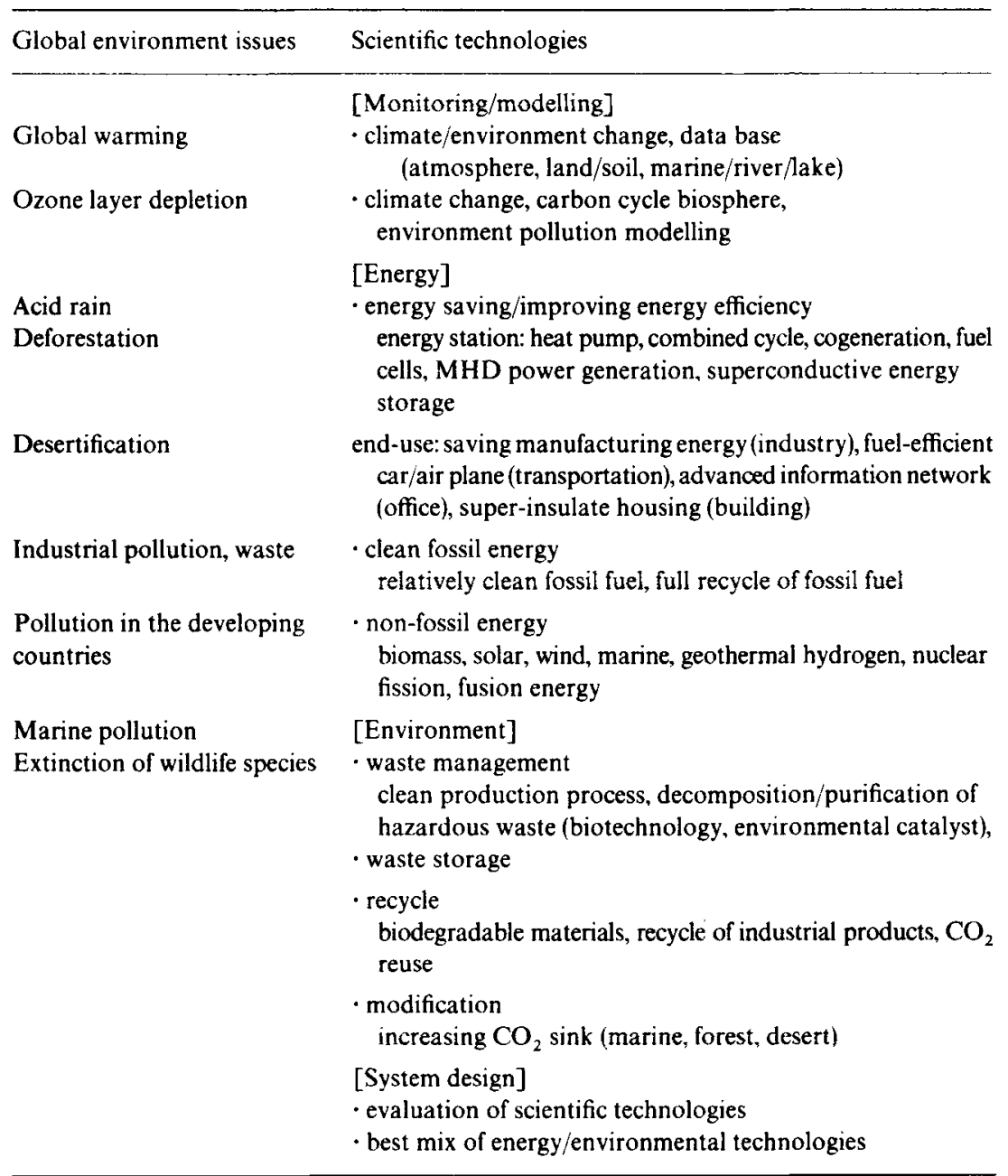

energy saving, clean energy and/or renewable energy, waste management, and materials recycling have been extensively studied in the world. Typical scientific technologies are listed in table 1 . Near term and long term research will be necessary for the establishment of these scientific technologies.

Among these global issues the global warming is one of a long term and worldwide issues (Ramanathan et al 1989). The global warming will be mainly caused by the emission of the greenhouse gas, $\mathrm{CO}_{2}$, produced by the power stations. However, the timing, magnitude and regional patterns of climate change, and their effects on the global ecosystem are not well understood. Uncertainties of this kind will remain and require a flexible $\mathrm{R} \& \mathrm{D}$ planning. The government of Japan has pointed out the global warming problem and proposed the action program. 'The New Earth 21' which has aimed to recover this planet over the coming 100 years by the development of scientific and technological means, calling for international coordination to promote comprehensive and sustainable action for the restriction and reduction of greenhouse gases which may cause the global warming as shown in figure 1 . It is stated that the first 50 


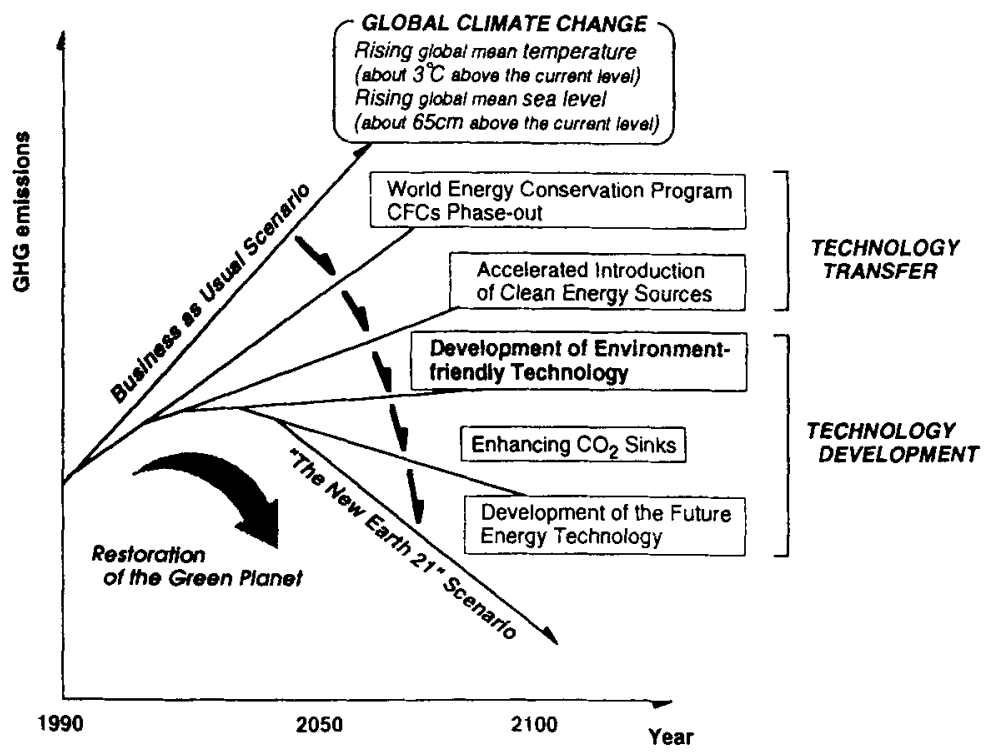

Figure 1. Concept of 'The New Earth 21': Action program for a reduction of GHG (greenhouse gas) emission in Japan.

Table 2. IEA greenhouse gas $R$ \& D programme.

\begin{tabular}{|c|c|c|c|}
\hline Timescale & Basic technology & $\mathrm{CO}_{2}$ capture & $\begin{array}{l}\mathrm{CO}_{2} \text { transportation } \\
\text { and disposal }\end{array}$ \\
\hline Present or near term & $\begin{array}{l}P F+F G D \\
\text { Natural gas fired combined } \\
\text { cycle plants }\end{array}$ & $\begin{array}{l}\text { MEA and other } \\
\text { physical/chemical } \\
\text { means } \\
\text { Sorption }\end{array}$ & $\begin{array}{l}\text { Chemicals feedstock } \\
\text { Enhanced oil recovery } \\
\text { Exhausted oil/gas wells }\end{array}$ \\
\hline \multirow[t]{2}{*}{$\begin{array}{l}\text { Emerging or medium } \\
\text { term }\end{array}$} & $\begin{array}{l}\text { Integrated gasification } \\
\text { combined cycle }\end{array}$ & Cryogenic & New chemicals \\
\hline & & Membranes & Salt domes/aquifiers \\
\hline \multirow[t]{3}{*}{ Long term } & $\begin{array}{l}\text { Combustion in oxygen and } \\
\mathrm{CO}_{2} \text { atmosphere }\end{array}$ & $\begin{array}{l}\text { Advanced } \\
\text { membranes }\end{array}$ & $\begin{array}{l}\text { Ocean disposal } \\
\text { (pipeline or ship) }\end{array}$ \\
\hline & $\begin{array}{l}\text { Possible extensions: retrofit } \\
\mathrm{CO}_{2} \text { combustion, gasification } \\
\text { topping cycles, fossil fuel } \\
\text { based MHD and fuel cells }\end{array}$ & & $\begin{array}{l}\text { Enhanced } \\
\text { photosynthesis } \\
\text { Biological fixation }\end{array}$ \\
\hline & & & $\begin{array}{l}\text { Disposal as a solid, } \\
\text { including hydrates }\end{array}$ \\
\hline
\end{tabular}

PF: Pulverised fuel (coal); FGD: Fuel gas desulphurisation: MEA:Monoethanolamine.

years should be devoted to technological improvement or scientific findings, the incorporation of energy saving and clean energy, the development of the greenhouse gas $\mathrm{CO}_{2}$ reduction and enhancement of $\mathrm{CO}_{2}$ sinks in the ocean and/or the aquiers for clean use of fossil fuel. and future generation energy as soon as each becomes feasible. 
The next 50 years should be devoted to carry out a large-scale reduction and restriction of the greenhouse gases.

The IEA (International Energy Agency) has also made research program on the greenhouse gas issues "IEA-GREENHOUSE GAS PROGRAMME" as shown in table 2 (IEA 1992). The program includes the evaluation of the basic technology to achieve the reduction, capture, and disposal of $\mathrm{CO}_{2}$ and the study of the full fuel cycle evaluation of $\mathrm{CO}_{2}$ mitigation options (Audus and Saroff 1994).

\section{Environment benign materials technologies}

\subsection{Basic concept}

The basis of a materials policy for a better global environment comprises following elements (Jackson 1991):

- phasing out all dissipative uses of hazardous materials,

- phasing out emission of persistent, synthetic materials,

- reducing raw material extraction and consumption,

- ensuring sustainable use of renewable resources,

- optimizing materials use with respect to product life,

- ensuring full life-cycle analysis is applied to material choices, and

- optimizing material flow with respect to natural material cycle.

Although wide varieties of materials technologies including ceramics materials technology have been used in production, whole traditional manufacturing technology could not meet the requirement for the protection of the environment. It is essential for us

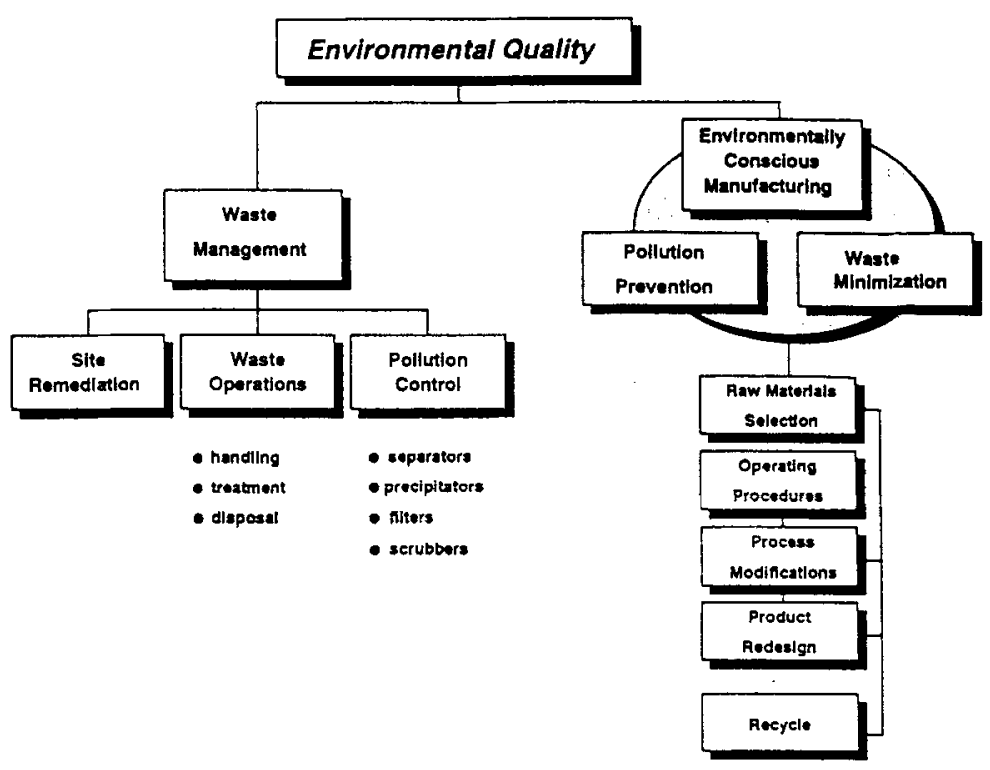

Figure 2. Environmental benign manufacturing (Watkins 1992). 


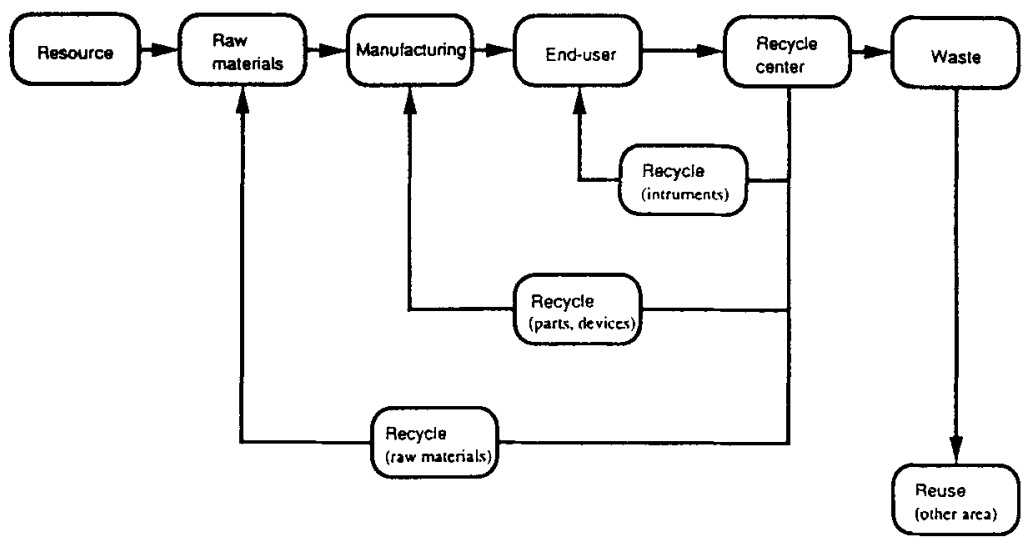

Figure 3. Full materials recycle system.

to establish the scientific and/or industrial materials technology with highly environmental quality which will provide the environment benign materials technology.

Several reports describe the concept on the environmental quality. Typical concept is shown in figure 2 (Watkins and Granoff 1992). The option concerning the waste management and/or the environment benign manufacturing means should be sincerely evaluated for a better environment.

The waste management including site remediation, pollution control, and waste handling/disposal comprises "end-of-pipe" measures to prevent discharge of waste. Future ceramics materials technologies should consider the environmentally benign manufacturing or "front-end" pollution prevention. The minimization of the waste and/or the front-end prevention of the pollution are essential for a better global environment.

It is also considered that future ceramics materials technology should be the full materials recycle system with the minimum environmental load as shown in figure 3 (Wasa 1994). In the full materials recycle system the minimum waste production will be expected. Minimum usage of hazardous materials and saving energy during the manufacturing will reduce the environmental load. The concept of materials design "kei-haku-tan-show" (light-thin-short-small) is one such candidate to meet the present environmental requirement (Yanagida 1991).

In the full materials recycle system the energy will be spent, (i) at the production of the source materials, (ii) at the manufacturing stage, (iii) at the end user, and (iv) at the recycling stage of the products. Total system energy consumption should be counted to evaluate the environmental load. The recycling essentially reduces the environmental load, if the energy consumption at recycle stage will not exceed the energy consumption of normal production system. The introduction of non-fossil renewable energy could reduce the environmental load which actually reduces the total system energy consumption. In the full materials recycle the global materials cycle should be also considered (Cohen 1994).

\subsection{Examples}

There are a number of studies on the materials technology to respond to the present environmental issues as shown in table 3 . In these technological studies it is important 
Table 3. Materials technologies for a better global environment.

\begin{tabular}{|c|c|}
\hline Materials technology & Application \\
\hline \multicolumn{2}{|c|}{ [monitoring/control $]$} \\
\hline $\begin{array}{l}\text { * } \\
\text { sensor/actuator } \\
\text { (integrated smart sensor) }\end{array}$ & $\begin{array}{l}\text { environment pollution monitoring } \\
\text { satellite ozone layer observing pollution control } \\
\text { (industry, cities, automobile) }\end{array}$ \\
\hline \multicolumn{2}{|c|}{ [saving energy] } \\
\hline * high temperature ceramics & high temperature gas turbine ceramic engine \\
\hline ** superconductors & $\begin{array}{l}\text { energy storage, power cable, generator, motor } \\
\text { information/communication device and system }\end{array}$ \\
\hline $\begin{array}{l}\text { * intelligent structural ceramics } \\
\text { (functional glass, heat insulator } \\
\text { selective coating) }\end{array}$ & $\begin{array}{l}\text { ecological housing } \\
\text { super insulated housing }\end{array}$ \\
\hline $\begin{array}{l}\text { * intelligent functional ceramics } \\
\text { (thin film, nanometer composite) }\end{array}$ & $\begin{array}{l}\text { information/communication device and system } \\
\text { sensor/actuator/robot }\end{array}$ \\
\hline $\begin{array}{l}\text { advanced materials processing } \\
\text { (microwave sintering, sol-gel } \\
\text { processing, atomic level deposition, } \\
\text { biochemical processing) }\end{array}$ & reduction of manufacturing energy \\
\hline \multicolumn{2}{|c|}{ [new energy] } \\
\hline $\begin{array}{l}\text { ** photovoltaic cells } \\
\text { (thin film, nanometer composite) }\end{array}$ & dry and wet solar battery \\
\hline $\begin{array}{l}\text { ** solid electrolyte } \\
\text { (thin film, thick film) }\end{array}$ & high temperature fuel cells \\
\hline $\begin{array}{l}\text { ** photo catalyst } \\
\text { (thin film, powder) }\end{array}$ & hydrogen production from water \\
\hline ** hydrogen storage & hydrogen energy source \\
\hline \multicolumn{2}{|c|}{$\begin{array}{l}\text { [environment] } \\
\text { (waste management/recycling) }\end{array}$} \\
\hline * photo catalyst & decomposition/purification of polluted water \\
\hline * glass ceramics & radio active waste storage \\
\hline ** porous ceramics & $\begin{array}{l}\text { forestation of desert man-made coral reef } \\
\text { (increasing } \mathrm{CO}_{2} \text { sink) }\end{array}$ \\
\hline ** ceramics membrane & $\begin{array}{l}\text { gas separation } \\
\text { purification of polluted water }\end{array}$ \\
\hline $\begin{array}{l}\text { ** environmental catalyst, high } \\
\text { temperature catalyst, photo } \\
\text { catalyst, honeycomb substrate }\end{array}$ & $\begin{array}{l}\text { reduction of environmental pollution } \mathrm{NO}_{x}, \mathrm{SO}_{x} \text {, } \\
\text { carbon diesel trap, gas turbine, catalytic } \\
\text { combustion, membrane reactor, reuse/recycle } \\
\text { of } \mathrm{CO}_{2}\end{array}$ \\
\hline ** composite structural ceramics & recycling structure/building \\
\hline
\end{tabular}

* near term ** medium/long term

for us to establish the novel environment benign materials technology, which will play an important role to counter measure the global environmental issues.

3.2a Energy saving-low temperature processing: The improvement of heating efficiency during the sintering of ceramics saves the manufacturing energy. Microwave 
sintering is one method for the low temperature sintering of ceramics, although the low efficiency of the present microwave generator limits the amount of saving energy (Saji 1994). It was also noted that mono-sintering process, which will be improvement of the traditional ceramics sintering process, could save the total sintering energy. For instance, from layers of green sheets ceramics multi-layered structure $\mathrm{PbO}-\mathrm{SiO}_{2}-$ $\mathrm{B}_{2} \mathrm{O}_{3}-\mathrm{Al}_{2} \mathrm{O}_{3} / \mathrm{BaTiO}_{3} / \mathrm{RuO}_{2}$ could be sintered at $900^{\circ} \mathrm{C}$ (Newnham 1994).

Lowering the sintering temperature saves the process energy consumption. In general the sintering temperature decreases with the decrease of particle size of ceramics raw materials before the sintering. The thin film deposition of ceramics on an atomic scale will realize the lowest sintering temperature, if we introduce ion/plasma processing. For instance plasma chemical vapour deposition and sputtering deposition lower the synthesis temperature of ceramics. High energy electron in the plasma excites the ion and promotes the decomposition and/or chemical reaction of source materials during deposition as shown in table 4 (Wasa et al 1991).

High temperature materials including SiC could be synthesized at temperature lower than $500^{\circ} \mathrm{C}$ (Wasa et al 1976). Epitaxial growth process could lower the growth temperature of $\mathrm{ZnO}$ single crystals as low as $100^{\circ} \mathrm{C}$ (Mitsuyu et al 1982). It is noteworthy that energetic carbon ions collide with each other on the substrate which will equivalently induce high pressure and high temperature during crystal growth resulting in the synthesis of diamond crystallites at room temperature (Kitabatake and Wasa 1985). Ion beam sputtered $\mathrm{Si}_{3} \mathrm{~N}_{4}$ thin films deposited at room temperature show high chemical and thermal stability similar to pyrolytic $\mathrm{Si}_{3} \mathrm{~N}_{4}$ thin films deposited at $1200^{\circ} \mathrm{C}$ as seen in table 5 (Kitabatake and Wasa 1986). Energy for production of

Table 4. Plasma enhanced chemical reactions.

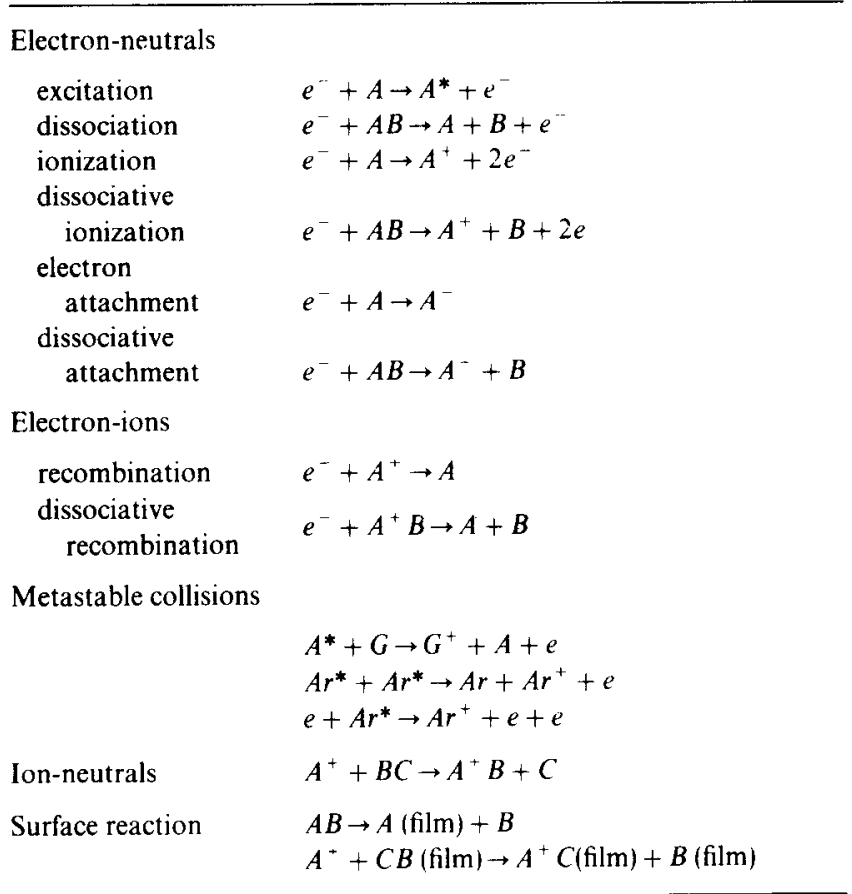


Table 5. Physical and chemical properties of ion beam sputtered silicon nitride thin films on Si substrate.

\begin{tabular}{|c|c|c|c|}
\hline & IBS & $\mathrm{HT}-\mathrm{CVD}$ & $\mathrm{P}-\mathrm{CVD}$ \\
\hline Sub. temp. & RT & $900^{\circ} \mathrm{C}$ & $300 \mathrm{C}$ \\
\hline Composition & $\mathrm{Si}_{3} \mathrm{~N}_{4}$ & $\mathrm{Si}_{3} \mathrm{~N}_{4}$ & $\mathrm{Si}-\mathrm{N}-\mathrm{H}$ \\
\hline Hydrogen & $\sim 0.1 \%$ & - & $\sim 10 \%$ \\
\hline HFB etch rate & $20 \mathrm{~A} / \mathrm{min}$ & $10-15 \mathrm{~A} / \mathrm{min}$ & $200-300 \mathrm{~A} / \mathrm{min}$ \\
\hline $\begin{array}{l}\text { Refractive } \\
\text { index }\end{array}$ & $2-2 \cdot 2$ & $2-2 \cdot 1$ & $2-2 \cdot 1$ \\
\hline \multicolumn{4}{|l|}{ Dielectric } \\
\hline constant & $6-7$ & $6-7$ & $6-9$ \\
\hline
\end{tabular}

plasma and ion should be included when total energy saving will be evaluated in the plasma and/or ions processing. Ceramics synthesis from liquid solution such as sol-gel method also lowers the synthesis temperature of crystalline ceramics (Mackenzie 1991).

The other promising process of low temperature synthesis is biomaterials. It is surprising that the avian eggshell comprising calcium carbonate is fabricated by aseptic processing at less than $40^{\circ} \mathrm{C}$ and with a unit production time of less than $24 \mathrm{~h}$ (Fink et al 1992). Biomineralization including enzyme catalytic process will also be a promising low temperature process for saving energy as well as lowering synthesis temperature by using the traditional metal and/or chemical catalyst.

3.2b Energy saving-amorphous materials: Instead of lowering the crystallizing and/or sintering temperature of ceramics materials, utilization of amorphous materials is a smart technology for saving energy. Typical example is the a-Si solar cells (Hamakawa 1990). The conventional single crystal Si-solar cells are produced at the temperature of about $1000^{\circ} \mathrm{C}$. The synthesis temperature of a-Si solar cells is as low as $300^{\circ} \mathrm{C}$. Although the a-Si solar cells exhibit lower convert efficiency, a-Si solar cells are the most promising solar cells due to their small energy consumption for the production of solar cells. Energy payback time (EPT) which describes the number of years that is required for solar cell modules to generate the same electric power at their fabrication stage should be considered for the evaluation of solar cells. At present a-Si solar cells show the shortest EPT of less than 5 years (Kuwano 1991).

3.2c Nonhazardous materials-waste minimization: Functional materials will often include hazardous substances like $\mathrm{Hg}$ and $\mathrm{Cd}$. For example, II-VI compounds solar cells including $\mathrm{Cd}-\mathrm{Se}$ will exhibit high conversion efficiency. $\mathrm{Tl}$ and $\mathrm{Hg}$ compounds provide high- $T_{\mathrm{c}}$ superconductors (Sheng and Hermann 1988; Putilin et al 1993). Thin film structures will minimize the waste of hazardous materials. Typical examples are surface acoustic wave (SAW) devices shown in figure 4 (Yamazaki et al 1980). The thin film SAW devices comprise piezoelectric thin films of $\mathrm{ZnO}, \mathrm{CdS}$, and/or GaAs deposited on nonhazardous $\mathrm{SiO}_{2}$ glass substrate. The thickness of the piezoelectric thin films is less than the wavelength of SAW. For the SAW devices used in colour television or video tape recorder (VTR) system the wavelength is 55.6 micronmeter in $\mathrm{ZnO} /$ glass structure for NTSC system in Japan. Since the piezoelectric bulk materials of $0.5 \mathrm{~mm}$ thick will be used for the conventional bulk SAW devices, thin film structure could reduce the waste by one tenth. It is also noted that the thin film structure induces high 


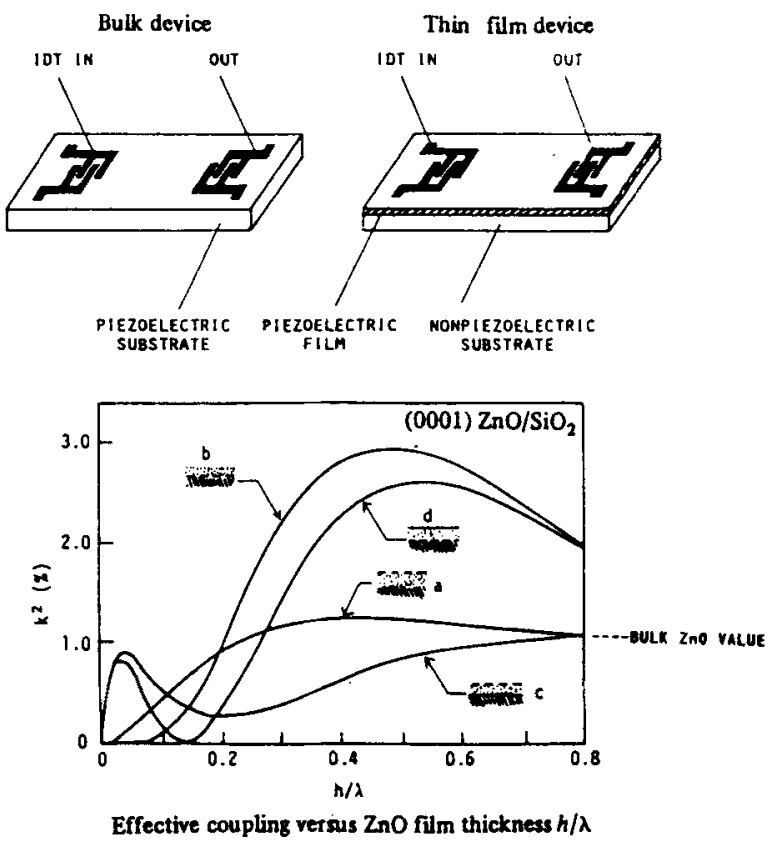

Figure 4. Basic construction of SAW devices. Thin films SAW structure shows higher electro-mechanical coupling coefficient, $k^{2}$, than bulk SAW devices.

Table 6. Waste minimization with materials saving: Thin film SAW filters.

\begin{tabular}{lcc}
\hline & $\begin{array}{c}\text { Bulk } \\
\text { SAW filter }\end{array}$ & $\begin{array}{c}\text { Thin film } \\
\text { SAW filter }\end{array}$ \\
\hline $\begin{array}{l}\text { thickness of piezoelectric } \\
\text { materials* } \\
\text { relative materials } \\
\text { consumption }\end{array}$ & $500 \mu \mathrm{m}$ & $1.5-25 \mu \mathrm{m}$ \\
\hline
\end{tabular}

\footnotetext{
* phase velocity, v: $2500 \mathrm{~m} / \mathrm{s}$, centre frequency, $\mathrm{f}: 50 \mathrm{MHz}$, thickness $=\mathrm{v} / 2 \mathrm{f}$
}

coupling due to thin film effect on the layered structure (Kino and Wager 1973). This results in the formation of low loss SAW devices which could not be realized by the bulk SAW devices. Conventional L-C circuits with amplifier comprising 20 components could be substituted by a thin film SAW device, which could reduce both energy consumption at the TV/VTR system and the component waste as shown in table 6 (Setsune et al 1979).

Nanometer composites shown in figure 5 are available to reduce the quantity of the use of hazardous materials (Wasa 1993) and show the possibility of lowering the sintering temperature of ceramics (Roy 1991). The combination of composite materials creates novel materials due to the quantum size effects. For example, semiconductor microcrystallites such as $\mathrm{CdS}$ doped in $\mathrm{SiO}_{2}$ glass matrices exhibit a blue shift at optical 

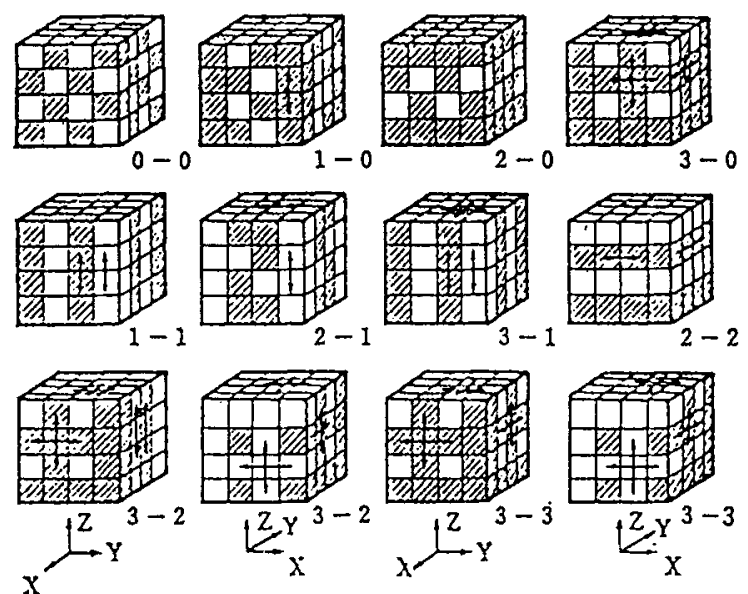

Figure 5. Nanometer composites for future functional ceramics.
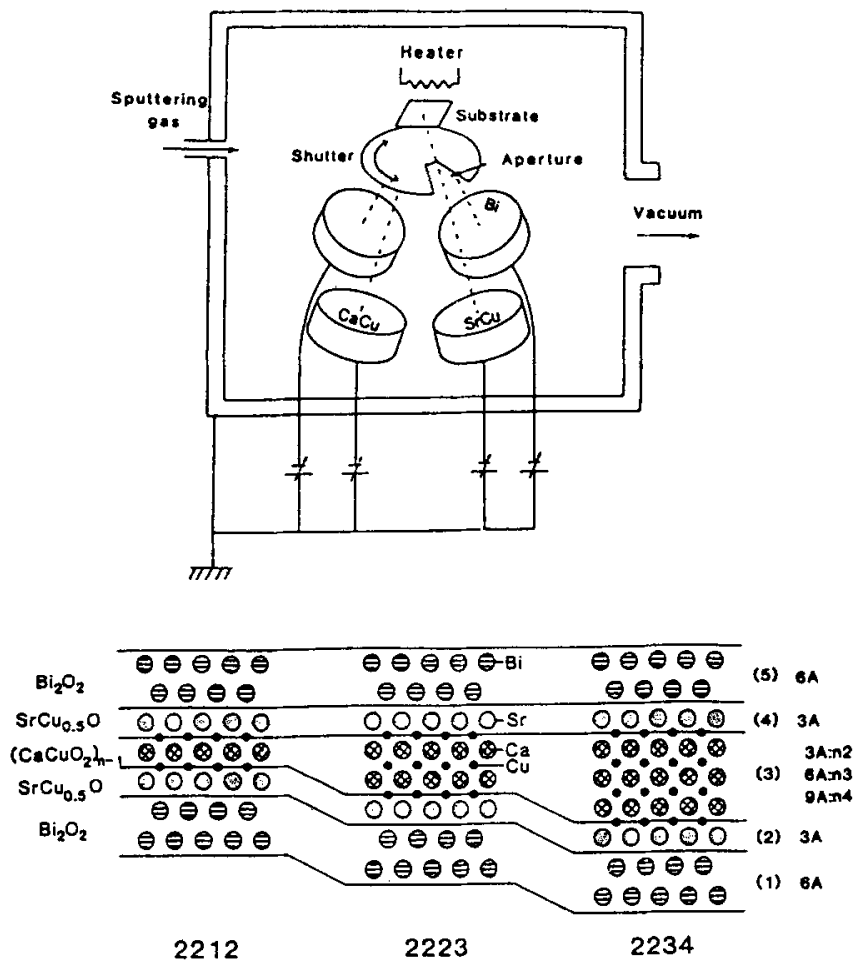

Figure 6. Layer-by-layer deposition of $\mathrm{Bi}-\mathrm{Sr}-\mathrm{Ca}-\mathrm{Cu}-\mathrm{O}$ by multi-target sputtering; alternate deposition in the order $(1) \rightarrow(2) \rightarrow(3) \rightarrow(4) \rightarrow(5)$.

transmission spectra due to a zero-dimensional confinement of electrons and holes in $\mathrm{CdS}$ microcrystallites. The diameter of microcrystallites is less than $100 \mathrm{~A}$, where the microcrystallites are considered as "quantum dots" (Tanahashi et al 1991). Layer-bylayer deposition on an atomic scale shown in figure 6 has the potential of creating 
man-made materials which will correspond to 2-2 structure of nanometer composite (Wasa et al 1991). The man-made superlattice structures of layered a-Si also exhibit the blue shift at optical transmission spectra. These nanometer composite structures including thin film layered structures could modify the nature of bulk materials and show the possibility of creating novel functional materials without using hazardous elements. The biomimetic ceramics and composite materials will provide environment benign materials (Calvet 1992).

3.2d Recycling: Typical example is recycling of glass. At present more than $50 \%$ of glass is reused in Japan (Matsumoto 1992). The glass recycling comprises recycling of glass bottle where collected glass is used as a cullet. The use of cullet saves the energy by $25 \%$ in the melting process of the glass. The validity of the recycling system is evaluated by the total energy consumption and the economical values of recycled materials. The separation and collection of used materials are essential to realize the recycling system. The other example is utilization of industrial waste at cement factory. The industrial waste produced outside the cement factory including blast furnace slag, fly ash, and waste tire. The separation conscious materials design will be important for the achievement of full recycling system.

\section{Discussion}

Environment benign materials technology is an important technology for the achievement of a better global environment. The materials technology should be considered in the following two research fields: (1) Reconstruction of the traditional materials technology and establishment of environment benign technology, and (2) application of the environment benign materials technology for the achievement of a better global environment.

The establishment of the environment benign technology will make a contribution not only to the application for a better environment but also for the promotion of basic science and technology. The environment benign technology could be applied for the recovery of domestic and global environment. The global environmental issues, however, cannot be solved only by a scientific technology but also by a reform of economic and social system in the world. The research program should be made in relation to the international agreement and/or regulations.

The present global environmental issues are essentially caused by the excess energy consumption and the marked growth of population. Under a given number of population an improvement of energy technology and waste management will be essential for the better global environment.

Since the clean energy such as fusion power generation will be developed after year 2050 , the fossil energy will be mainly used during the coming century as indicated in figure 7 (IPPC 1990). The use of fossil fuel will emit hazardous gases including $\mathrm{SO}_{x}$, $\mathrm{NO}_{x}$, and $\mathrm{CO}_{2}$ which will cause the acid rain and/or global warming. The technologies for the suppression of the $\mathrm{SO}_{x}$ and $\mathrm{NO}_{x}$ have been already established and are used in practise chiefly in developed countries. How to reduce the $\mathrm{CO}_{2}$ emission will be present essential research area.

At the Rio Summit the limitation of the $\mathrm{CO}_{2}$ emission for each developed country has been discussed, ex. 1990 level of the $\mathrm{CO}_{2}$ emission in year 2010 in Japan. In order to keep the $\mathrm{CO}_{2}$ emission in the level of international agreement, the world energy 


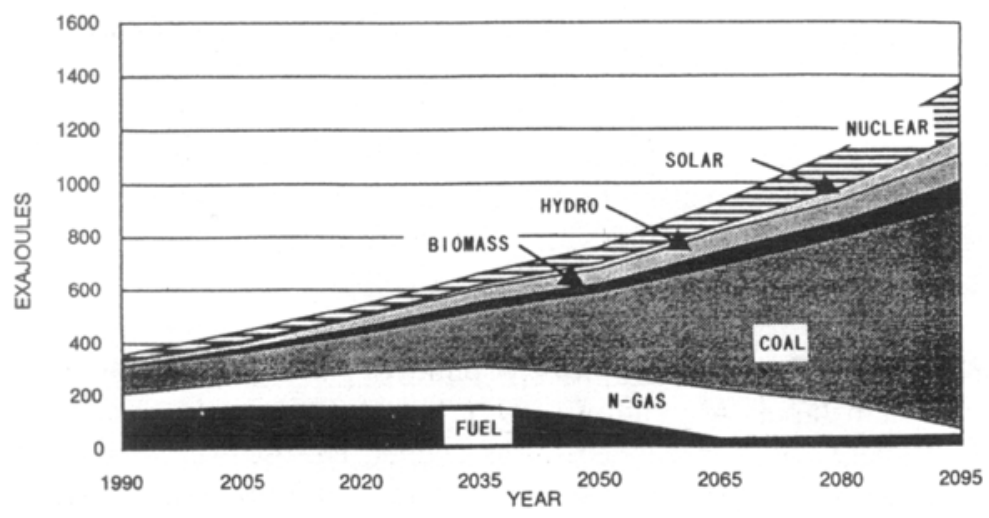

Figure 7. Primary energy for the coming century (IPPC 1990).

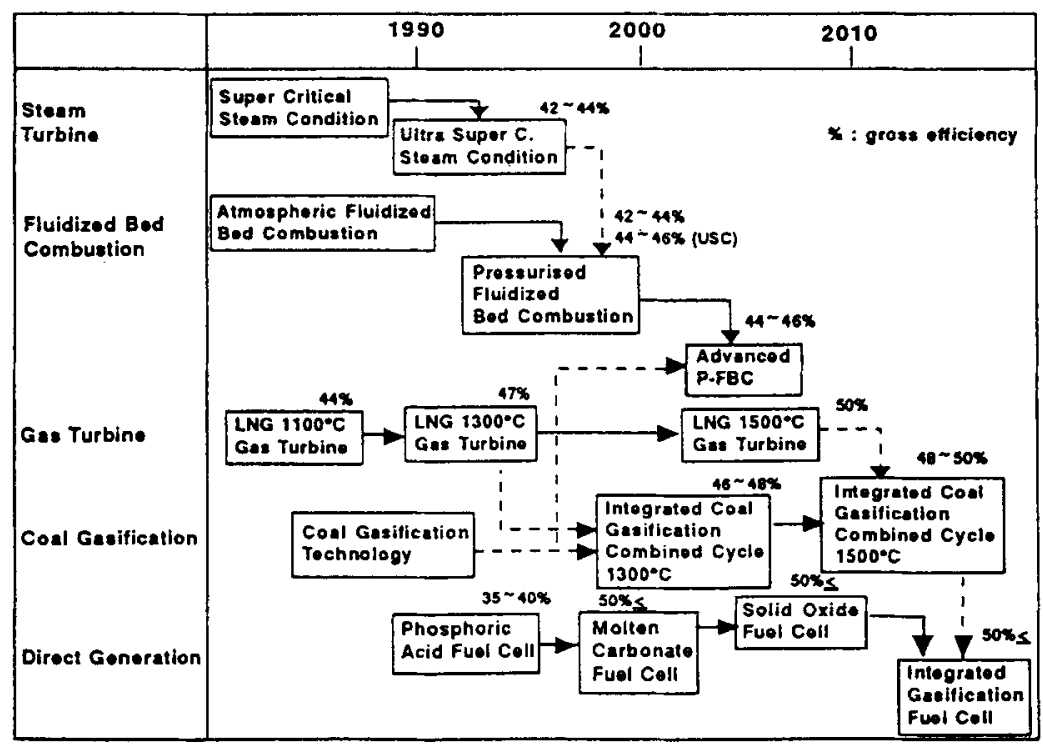

Figure 8. R \& D for high efficiency power generation in Japan.

consumption should be reduced by $20-30 \%$ at year 2010 . The fuel switching from coal to natural gas is available for the reduction of $\mathrm{CO}_{2}$ emission, since $\mathrm{CO}_{2}$ emission from natural gas at power plants, $0.21 \mathrm{~g} / \mathrm{kcal}$, is about half of the emission from coal power plant (Kaya 1994). At present the reduction of $\mathrm{CO}_{2}$ emission could be mainly realized by the energy saving.

For energy saving we should improve the efficiency at the power station and end-use. Several approaches have been studied for the increase of the efficiency at the power station. Figure 8 shows a typical research program for high efficiency fossil power generation technology in Japan. This type of research program has been also studied in IEA, the views are essentially in agreement (Audus 1993).

Conventional steam turbine at operating temperature of about $550^{\circ} \mathrm{C}$ shows the efficiency of $40 \%$ maximum. Higher efficiency will be achieved at higher operating 
Table 7. Electricity demand by sector and selected end-uses.

\begin{tabular}{|c|c|c|c|}
\hline & Japan & $\begin{array}{l}\text { United } \\
\text { States }\end{array}$ & IEA \\
\hline Total electricity final consumption (TWh) & 595 & 2275 & 4781 \\
\hline ... Industry share & $59 \%$ & $32 \%$ & $41 \%$ \\
\hline - Residential share & $25 \%$ & $36 \%$ & $32 \%$ \\
\hline - Commercial/Public share & $14 \%$ & $32 \%$ & $25 \%$ \\
\hline - Other (Transport, Agriculture and Other) & $3 \%$ & * & $2 \%$ \\
\hline \multicolumn{4}{|l|}{ Shares of which } \\
\hline - Residential space heating (2) & $3 \cdot 1 \%$ & $4 \cdot 3 \%$ & $47 \%$ \\
\hline - Residential water heating (2) & $3.0 \%$ & $5 \cdot 4 \%$ & $5.4 \%$ \\
\hline - Residential refrigeration (2) & $6.5 \%$ & $7 \cdot 4 \%$ & $6.8 \%$ \\
\hline - Lighting & n.a. & $18 \cdot 5 \%$ & $16 \cdot 7 \%$ \\
\hline - Commercial/Public building space conditioning & $1.7 \%$ & $13 \cdot 5 \%$ & $9 \cdot 9 \%$ \\
\hline - Industrial motors & $42 \cdot 1 \%$ & $22 \cdot 5 \%$ & $27.0 \%$ \\
\hline Total share of selected end-uses & n.a. & $71 \cdot 2 \%$ & $70.5 \%$ \\
\hline
\end{tabular}

n.a.: not availạble

temperature. The gas turbine at operating temperature of $1100^{\circ} \mathrm{C}$ with the efficiency of $44 \%$ is already used in practice. The gas turbine at operating temperature of $1500^{\circ} \mathrm{C}$ and the integrated coal gasification combined cycle (IGCC) will achieve the efficiency up to $50 \%$. These power generation systems will play an important role to achieve the present international regulation of the $\mathrm{CO}_{2}$ emission. The development of the high temperature ceramics up to $1500 \mathrm{C}$ is one of the most important research areas at present. In future the magneto-hydro-dynamics (MHD) generation will be used for further increase of the efficiency, which will operate at very high temperature of $2500-2700^{\circ} \mathrm{C}$, although the engineering problem of operation at such high temperature is considerable and the technology is many years from being a reality.

The energy saving should be also done at end-uses. The electricity final consumption comprises industry, residential, and commercial/public share as shown in table 7 (IEA 1989). It is seen that residential space heating and water heating, residential refrigeration, and commercial/public building space condition have $40-50 \%$ and industrial motors have $20-40 \%$ of the total end-uses. Saving energy at residential space/building for heating and at industry for motors will be indispensable.

For the ceramics materials manufacturing the low temperature sintering should be further studied. Atomic level sintering including vapour phase and liquid phase synthesis is used to achieve the minimum energy consumption for ceramics sintering. For the synthesis from solution crystalline zinc ferrite has been synthesized near room temperature through the so-called green-rust phase containing $\mathrm{Fe}^{+2}, \mathrm{Fe}^{+3}, \mathrm{Zn}^{+2}$, $\mathrm{OH}^{-1}, \mathrm{Cl}^{-1}$ (Myers 1994). This indicates that the selection of appropriate phase achieves the low temperature synthesis of ceramics. The application of geothermal energy and isostatic high pressure under the ocean are also useful for saving fossil energy. The materials technology including structural and/or functional glass such as heat reflective window glass for ecological housing and/or office are effective technologies to meet the present social demand. The possibility of the energy saving at end-uses has been estimated in detail (Nakicenovic 1993). 


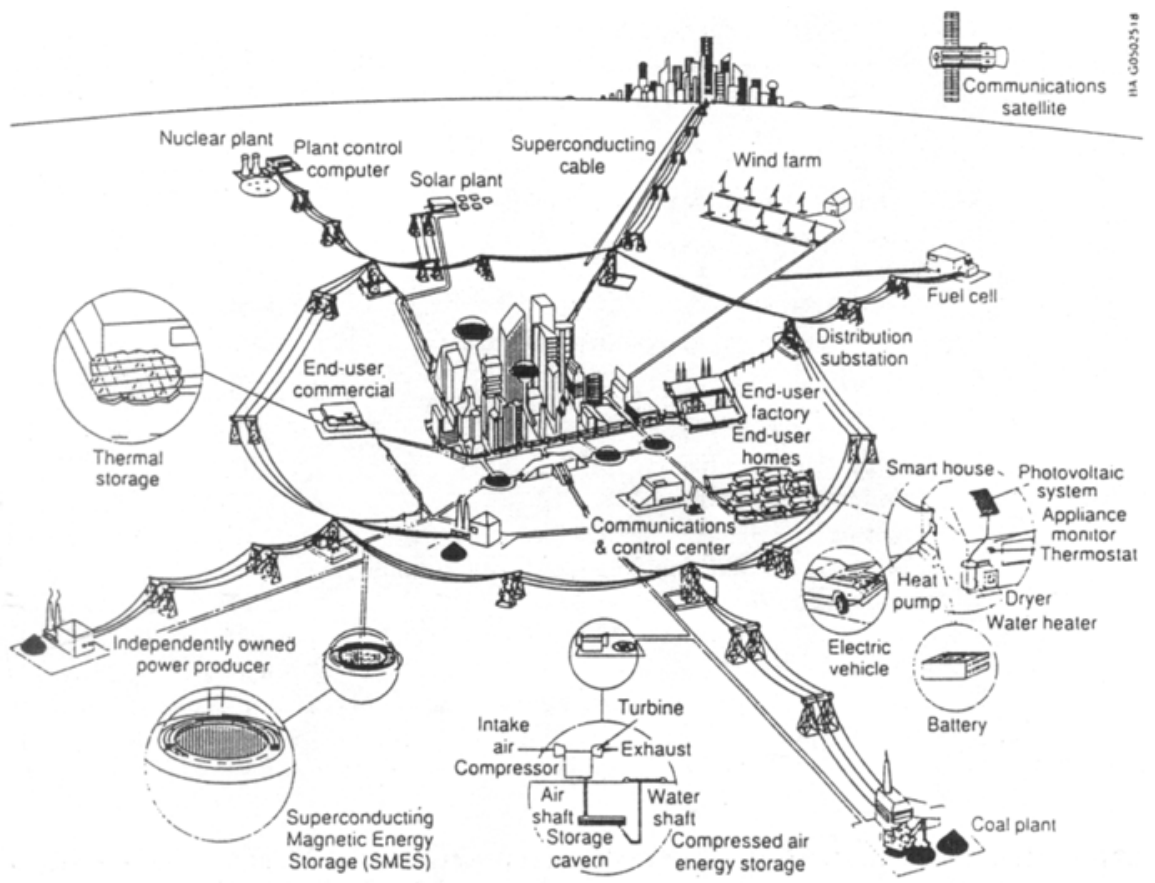

Tomorrow's electricity network will incorporate elements such as renewable energy systems. long-term energy storoge. and inde pendent poucer producers. This diverse mix of generoting capacity will result in special challenges to the reliability and safety of our electricity supply.

Figure 9. Future hybrid energy system comprising traditional fossil energy and non-fossil energy proposed by DOE.

It is noted that in future electric power will be supplied by distributed power stations as shown in figure 9 (Wasa 1992). Wide varieties of energy sources include solar cells and fuel battery. High- $T_{\mathrm{c}}$ superconductors will save the energy at power transmission line, power station and power storage. High temperature fuel battery will be used with MHD power generators.

The long-term energy technology scenarios have been extensively studied in the world to meet global environment requirements. These scenarios include both the fossil fuel energy and nuclear fission energy during the next century, even if the nuclear fusion energy will be introduced in practice. It is also noted that the long term energy scenarios will be strongly affected by the political system including an introduction of the carbon tax for the $\mathrm{CO}_{2}$ emission as shown in figure 10 (Clarke 1991). The carbon tax will reduce the use of coal at power station.

For the recycle of fossil fuel waste gas $\mathrm{CO}_{2}$ released from power station should be converted into fuel such as methanol. The energy consumption at recycle stage will essentially exceed the energy generated at initial stage, the natural energy including solar energy should be introduced for the recycle stage. Although on site recycle of fossil fuel at power station is desired to simplify the recycle system, low density of solar energy will prevent on site conversion of $\mathrm{CO}_{2}$ (Masuda 1994). Off site recycle and/or delayed recycle system with long period of recycle time will be introduced. The ceramics materials technology related the $\mathrm{CO}_{2}$ removal and/or recycle including gas separation membrane of porous glass and/or zeolite for high temperature operation (Yazawa 

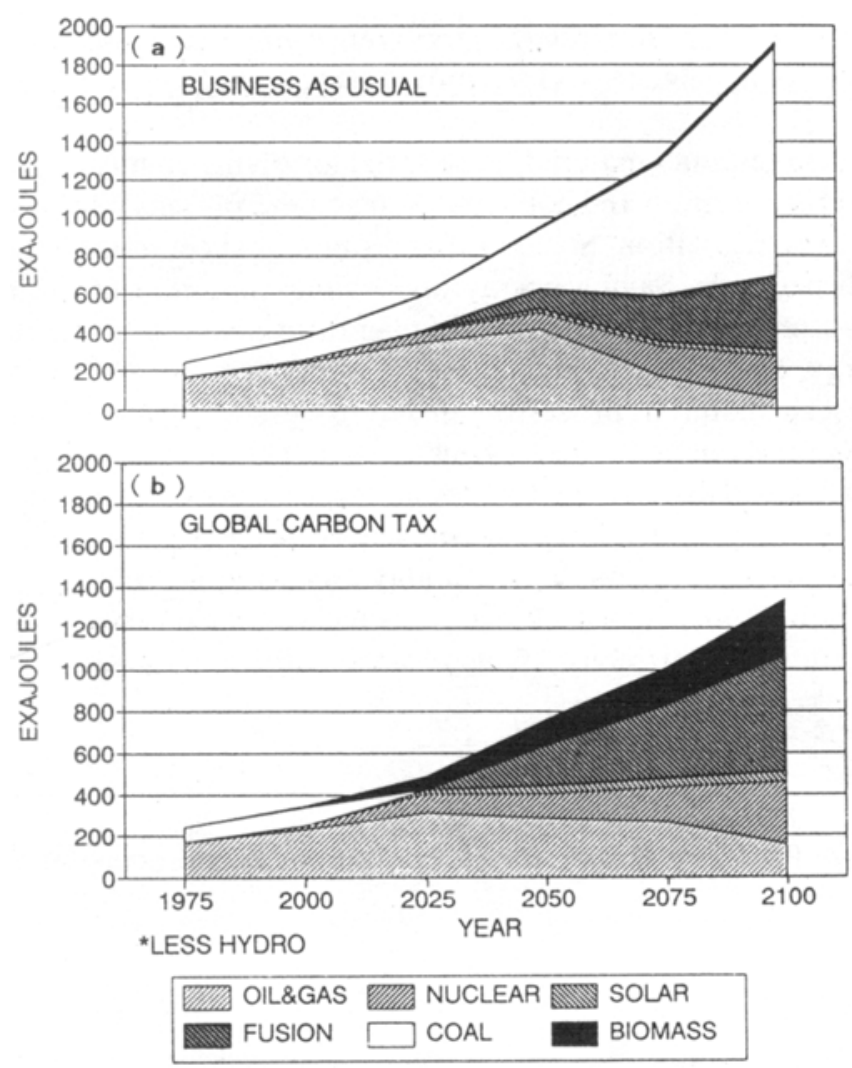

Figure 10. Modelling of future energy system: (a) without carbon tax and (b) with carbon tax (Clarke 1991).

1994 ) is considered as a long term research area. The nuclear waste problem will exist from now until the next century. Ceramics materials technology for storage/recycle of nuclear waste will be an emerging research area.

The prevention of water pollution and/or purification of polluted water by ceramics materials including photo-catalyst and membrane reactor are other problems to be studied. Environmental catalyst for the reduction of hazardous gas species including $\mathrm{NO}_{x}$, $\mathrm{SO}_{x}$, and hydrocarbon released from diesel engine is dispensable at present. Decomposition of water for the production of hydrogen using $\mathrm{TiO}_{2}$ photo-catalyst will be important to build resourceful energy technology in future (Fujishima and Honda 1972).

\section{Conclusion}

Present global issues will be solved by the resourceful energy technology under a minimum pollution of environment. Energy technology and waste management are essential to achieve a better global environment. The environment benign materials technology should be applied for energy saving and waste management.

The research scenarios include near term and long term research areas. Energy saving and domestic waste management are short term research areas. Medium and 
long term research areas are non-fossil energy (renewable energy and nuclear fusion) and global waste management $\left(\mathrm{CO}_{2}\right.$ removal/recycle and nuclear waste storage/ recycle).

High temperature ceramics materials is essential for saving energy at power station, industry, cities, transportation and contributes to achieve present international agreement including $\mathrm{CO}_{2}$-regulation. Structural and functional ceramics for eco-housing will be also indispensable. Saving energy at ceramics sintering including lowering synthesis temperature, application of low temperature phase, introduction of solar/ geothermal energy, and isostatic high pressure under the ocean should be further studied. Atomic scale materials processing including surface chemical reaction will be available not only for reduction of hazardous waste but also for saving energy. Highly functional materials will be created by atomic level materials processing including high- $T_{\mathrm{c}}$ superconductors, global environment sensor, solar cells, and functional catalyst. The ceramics materials technology will play an important role from now till the next century, although impact of each materials technology on the protection of the global environment will be strongly affected by the political measures.

\section{Acknowledgement}

The author thanks Prof. Jiro Kondo for his continuous encouragement.

\section{References}

Audus H 1993 Greenhouse gas releases from fossil fuel power stations (London: IEA GHG/SRI) p. 59

Audus $\mathrm{H}$ and Saroff $\mathrm{L} 1994$ Proc. 2nd international conference on carbon dioxide removal, (eds) J Kondo, T Invi and K Wasa (Tokyo: Pergamon) p. 831

Calvet P 1992 MRS Bull. 1737

Clarke J F 1991 Proc. IE A international conference on technology responses to global entironmental challenges, Kyoto, p. 364

Cohen M 1994 MRS Bull. 193

Fink D J, Caplan A I and Heuer A H 1992 MRS Bull. 1727

Fujishima A and Honda K 1972 Nature 23837

Hamakawa Y 1990 Proc. 1st world renewable energy congress, in Energy and environment, (ed.) A A M Sayigh (New York: Pergamon) vol. 1, p. 39

IEA 1989 Rept. Electricity end-use efficiency (Paris: OECD/IEA) p. 13

IEA 1992 Greenhouse Issues, No. 2

IPPC 1990 Rept.

Jackson T 1991 Proc. joint international symposium on environmental consequences of hazardous waste disposal (Stockholm: Swedish Ministry of the Environment) vol. 1, p. 39

Kaya Y 1994 Proc. 2nd international conference of carbon dioxide removal, Kyoto, preliminary lecture

Kino G S and Wager R S 1973 J. Appl. Phys. 441480

Kitabatake M and Wasa K 1985 J. Appl. Phys. 581693

Kitabatake M and Wasa K 1986 Appl. Phys. Lett. 49927

Kuwano Y 1991 Proc. IEA international conference on technology responses to global entironmental challenges. (K yoto: RITE), p. 245

Mackenzie J D 1991 Proc. centennial international symp. ceramics toward the 21st century, (eds) N Soga and A Kato (Tokyo: The Ceramic Society of Japan) p. 597

Masuda S 1994 Proc. 2nd international conference on carbon dioxide removal. Kyoto, paper 0-3-1

Matsumoto I 1992 Bull. Ceram. Soc. Jpn. 271066

Mitsuyu T, Yamazaki O and Wasa K 1982 J. Cryst. Growth 42233

Myers F S 1994 MRS Bull. 1910 
Nakicenovic $N$ (ed.) 1993 Long-term strategies for mitigating glohal warming (Oxford: Pergamon) p. 539

Newnham R E 1994 priyate communication

Putilin S N, Antipov E V. Chmaissem O and Marezio M 1993 Nature 362226

Ramanathan V, Barkstrom B R and Harrison E F 1989 Phys. Today 4222

Roy R 1991 Proc. centennial internationai sımp. ceramics trward the 21st century (eds) N Soga and A Kato

(Tokyo: The Ceramic Society of Japan) p. 161

Saji T 1994 Bull. Ceram. Soc. Jpn. 29383

Setsune K, Isobe M and Fujiwara Y 1979 National Tech. Repts. 25588

Sheng Z Z and Hermann A M 1988 Nature 332138

Tanahashi I, Yoshida M and Mitsuyu T 1991 Bull. Chem. Soc. Jpn. 642281

Wasa K 1992 J. IEICE Jpn. 75640

Wasa K 1993 Bull. Mater. Sci. 16643

Wasa K 1994 New Ceramics 729

Wasa K, Nagai T and Hayakawa S 1976 Thin Solid Films 31235

Wasa K, Adachi H, Ichikawa Y. Matsushima Y and Setsune K 1991 J. Mater. Res. 61595

Watkins R D and Granoff B 1992 MRS Bull. 1734

Yamazaki O. Mitsuyu T and Wasa K 1980 IEEE Trans. Sonics \& U'trason. SU-27 369

Yanagida H 1991 Proc. centennial international symp. ceramics toward the 21 st century, (eds) $N$ Soga and A Kato (Tokyo: The Ceramic Society of Japan) p. 81

Yazawa T 1994 New Ceramics 755 